\title{
Frequency of Deep Venous Thrombosis after Abdominal Surgery
}

Tahir Aslam, Shahzada Amir, Saira Batool, Nabeela Zia, Samia Rasool Tabassum, Muhammad Saleem Iqbal, Arslan Ahmed Salam

\section{ABSTRACT}

Objective: To determine the frequency of deep venous thrombosis after abdominal surgery. Study Design: Cross Sectional Study. Settings: Department of Surgery, Bolan Medical Complex, Quetta Pakistan. Duration: Six-months started from 14-06-2014 to 13-12-2014. Methodology: All patients with age 40 years to 70 years of either gender presented with ASA status I or II underwent major abdominal operations lasting more than 30 minutes were enrolled. Patients were followed for 7th postoperative day and final outcome that is DVT was assessed. Results: Patients mean age was $58.40 \pm 9.59$ years. Female preponderance was found to be higher, i.e. $47(53.40 \%)$. Mean BMl of the patients was $25.3 \pm 5.4 \mathrm{Kg} / \mathrm{m} 2$. There were $58(65.9 \%)$ patients with HTN, $34(38.60 \%)$ smokers and $42(47.70 \%)$ diabetic patients. There were $14(15.90 \%)$ DVT cases were reported. Conclusion: The frequency of deep venous thrombosis was found in 14 (15.90) patients after abdominal surgery.

Keywords: Deep venous thrombosis, Abdominal surgery, Diabetic patients.

Corresponding Author

Submitted for Publication: 16-09-2019

Accepted for Publication: 31-01-2020

ARSLAN AHMED SALAM, Research Officer, PHRC Central Research Centre, NIH, Islamabad, Pakistan

Contact / Email: +92 333-5615658, arslan_ahm691@hotmail.com

Citation: Aslam T, Amir S, Batool S, Zia N, Tabassum SR, Iqbal MS, Salam AA. Frequency of Deep Venous Thrombosis after Abdominal Surgery.

APMC 2020;14(1):5-8.

\section{INTRODUCTION}

Venous thrombo-embolism (VTE), one of the leading cause of mortality and its prophylaxis in the surgical community is becoming increasingly important and prevalent. ${ }^{1}$ Recently, researches suggests that more than 900000 cases occur annually, with one-third of those ultimately having a fatal pulmonary.2,3 Around 40\% patients of surgical department develop deep venous thrombosis, in the absence of prophylaxis \& with a 2-fold increase in incidence if the patient has a concomitant malignant outcome. ${ }^{4}$ Previous evidence suggested that patients undergoing high risk abdominal surgeries in around a quarter patient received no VTE prophylaxis, while one-half received inadequate preventive measures. ${ }^{5}$ Surgeons have long resisted adoption of aggressive chemoprophylaxis methods because of bleeding concerns. However, more recent data suggest that complications like bleeding in surgery patients who received prophylaxis occur is $<3 \%$ of cases, and these complications are reduced when lower-dose chemoprophylaxis isused. ${ }^{6}$ One of the best studied populations comes from the Apollo Trial, which demonstrated nearly a $70 \%$ reduction VTE when chemoprophylaxis was combined with mechanical methods and a bleeding rate of $1.6 \%{ }^{7}$

While the frequency and severity at VT in several surgical subspecialties is well documented, data regarding DVT development after general surgical operations is less compelling. A study in Uganda showed $5 \%$ prevalence of DVT in patients who underwent abdominal surgery. ${ }^{8}$ In another study, Upper extremity DVT's occurred in $40 \%$; lower extremity DVTs occurred in $45.7 \%$ in patients who underwent surgery. ${ }^{9}$ The frequency of postoperative DVT after high-risk surgery in a local study was found to be $12.82 \% .{ }^{10}$

The rationale of the study is to gain clarity in the burden as various studies showing differences in DVT after surgery. $8-10$ After the data collection of this study actual magnitude of DVT could be known and therefore strategies could be designed to cut down the morbidity and mortality secondary to DVT.

\section{METHODOLOGY}

Study Design: Cross Sectional Study.

Settings: Bolan Medical complex Quetta Pakistan in the Department of Surgery.

Duration: Six months from June 14, 2014 to December 2014.

Sample Technique: Non probability consecutive sampling.

Sample Size: 88

Inclusion Criteria: Patients with age between 40 years to 70 years, undergoing abdominal surgeries lasting greater than thirty minutes, either gender, with ASA status I \& II.

Exclusion Criteria: Patients having bleeding disorders, active peptic ulcer, bleeding hemorrhoids, history of upper gastrointestinal bleed stroke, intracranial hemorrhage, recent history of major trauma in preceding 2 weeks, renal failure allergy to heparin, platelet count less than $1 \times 106 / \mathrm{mm} 3$, hemoglobin less than $10 \mathrm{gm} / \mathrm{dl}$. The sample size of the study was 88 patients after prevalence of $12.8 \%$.

Methods: Past history regarding Hypertension for $>2 y r s$, smoking status 10 pack per year and the Diabetes Mellitus for $>$ 2yrears was taken. Patients were assessed for obesity and $\mathrm{BM} 1>30 \mathrm{~kg} / \mathrm{m} 2$ was labelled as obese. The consultant having post fellowship experience of greater than two years performs the surgery. Patients were followed for 7th postoperative day and final outcome that is DVT was assessed as clinically on the basis of pain and tenderness and ultrasound Doppler showing no pulsations.

Data analysis was done by using SPSS 11 . Mean \pm SD was calculated for age, weight, height, duration of DM, HTN and smoking and BMI, Obesity, DVT, gender, comorbids (DM, HTN), ASA status and smoking status was presented as frequency and percentages. Effect modifiers like comorbids (DM, HTN), 
duration of comorbids, smoking status, duration of smoking, age, gender, ASA status and BMl was done to controlled through stratification. Chi square testing was applied and statistical significance was taken as $<=0.05$.

\section{RESULTS}

Mean age of the patients was $58.40 \pm 9.59$ years (Table 1). Most of the patients presented with $>50$ years of age, i.e. 70 $(79.50 \%)$. Female preponderance was found to be higher, i.e. $47(53.40 \%)$. Mean weight of the patients was $61 \pm 5.02 \mathrm{~kg}$ (Table 1). There were $44(50 \%)$ patients with $\leq 60 \mathrm{~kg}$ and similar $44(50 \%)$ in $>60 \mathrm{~kg}$ patients and mean height of the patients was $1.54 \pm 0.62$ meter. Majority of the patients $56(63.60 \%)$ had $\leq 1.60$-meter height. Mean BMl of the patients was $25.3 \pm 5.4 \mathrm{Kg} / \mathrm{m} 2$ (Table 1).

Table 1: Demographics

\begin{tabular}{|c|c|}
\hline Demographic variables & $\begin{array}{c}\text { Mean } \pm S D \\
n=88\end{array}$ \\
\hline $\begin{array}{l}\text { Age in years } \\
\text { Mean } \pm S D\end{array}$ & $58.4 \pm 9.59$ \\
\hline Weight of patients in $\mathrm{kg}$ & $61 \pm 5.02$ \\
\hline $\begin{array}{l}\text { Height of the patients } \\
\text { (in meters) Mean } \pm S D\end{array}$ & $1.54 \pm 0.62$ \\
\hline $\begin{array}{l}\text { BMl of the patients (in } \mathrm{kg} / \mathrm{m}^{2} \text { ) } \\
\text { Mean } \pm S D\end{array}$ & $25.3 \pm 5.4$ \\
\hline $\begin{array}{l}\text { DM of the patients (in years) } n=42 \\
\text { Mean } \pm S D\end{array}$ & $4.7 \pm 1.87$ \\
\hline $\begin{array}{l}\text { HTN of the patients (in years) } n=57 \\
\text { Mean } \pm S D\end{array}$ & $3.1 \pm 1.18$ \\
\hline $\begin{array}{l}\text { Smoking duration of the patients (in years) } \\
n=61 \text { Mean } \pm S D\end{array}$ & $11.8 \pm 1.70$ \\
\hline
\end{tabular}

Obesity was found in $65(73.90 \%)$ patients. Mean duration of diabetes was $4.7 \pm 1.87$ years. Most of the patients $26(61.90 \%)$ had $\leq 5$ years duration of diabetes. Mean HTN of the patients was $3.1 \pm 1.18$ years. Most of the patients $45(78.90 \%)$ patients had $>2$ years of duration of HTN. Mean duration of smoking was $11.8 \pm 1.70$ years. Most of the patients $54(88.50 \%)$ patients had $>10$ years of duration of smoking status.

Table 2: Frequency of comorbids \& risk factors

\begin{tabular}{|c|c|}
\hline Demographic variables & Frequency (percentages) $\mathbf{n}=\mathbf{8 8}$ \\
\hline HTN & $58(65.9 \%)$ \\
\hline Smoking status & $34(38.60 \%)$ \\
\hline Diabetes mellitus & $42(47.70 \%)$ \\
\hline DVT & $14(15.90 \%)$ \\
\hline
\end{tabular}

ASA status I was found in $42(47.70 \%)$ patients and ASA status II was found in $46(52.30 \%)$ patients. There were $58(65.9 \%)$ patients with HTN, 34 (38.60\%) smokers and $42(47.70 \%)$ diabetic patients. DVT was found in 14 (15.90) patients.

Comparison was done with regards to comorbids (DM, HTN), duration of comorbids, smoking status, and duration of smoking, age, gender, ASA status and obesity with DVT.
Table 3: Comparison of DVT with characteristics of the patients $(n=88)$

\begin{tabular}{|c|c|c|c|c|c|}
\hline & \multicolumn{2}{|c|}{$\begin{array}{l}\text { Deep Venous } \\
\text { Thrombosis }\end{array}$} & \multirow[t]{2}{*}{ Total } & \multirow{2}{*}{$\begin{array}{c}p- \\
\text { value }\end{array}$} \\
\hline & & Yes & No & & \\
\hline \multirow[b]{2}{*}{ Age } & $\leq 50$ & $\begin{array}{c}6 \\
(33.3)\end{array}$ & $\begin{array}{c}12 \\
(66.7)\end{array}$ & $\begin{array}{c}18 \\
(100)\end{array}$ & \multirow[b]{2}{*}{0.034} \\
\hline & $>50$ & $\begin{array}{c}8 \\
(11.4) \\
\end{array}$ & $\begin{array}{c}62 \\
(88.6) \\
\end{array}$ & $\begin{array}{c}70 \\
(100)\end{array}$ & \\
\hline \multirow{2}{*}{ Gender } & Male & $\begin{array}{c}11 \\
(26.8) \\
\end{array}$ & $\begin{array}{c}30 \\
(73.2) \\
\end{array}$ & $\begin{array}{c}41 \\
(100)\end{array}$ & \multirow{2}{*}{0.017} \\
\hline & Female & $\begin{array}{c}3 \\
(6.4)\end{array}$ & $\begin{array}{c}44 \\
(93.6)\end{array}$ & $\begin{array}{c}47 \\
(100)\end{array}$ & \\
\hline \multirow{2}{*}{ Obesity } & Yes & $\begin{array}{c}12 \\
(18.5)\end{array}$ & $\begin{array}{c}53 \\
(81.5)\end{array}$ & $\begin{array}{c}65 \\
(100)\end{array}$ & \multirow{2}{*}{0.340} \\
\hline & No & $\begin{array}{c}2 \\
(8.7)\end{array}$ & $\begin{array}{c}21 \\
(91.3)\end{array}$ & $\begin{array}{c}23 \\
(100)\end{array}$ & \\
\hline \multirow{2}{*}{$\begin{array}{l}\text { Smoking } \\
\text { Status }\end{array}$} & Yes & $\begin{array}{c}11 \\
(32.4)\end{array}$ & $\begin{array}{c}23 \\
(67.6)\end{array}$ & $\begin{array}{c}34 \\
(100)\end{array}$ & \multirow{2}{*}{0.002} \\
\hline & No & $\begin{array}{c}3 \\
(5.6) \\
\end{array}$ & $\begin{array}{c}51 \\
(94.4) \\
\end{array}$ & $\begin{array}{c}54 \\
(100) \\
\end{array}$ & \\
\hline \multirow{2}{*}{ DM } & Yes & $\begin{array}{c}9 \\
(21.4) \\
\end{array}$ & $\begin{array}{c}33 \\
(78.6) \\
\end{array}$ & $\begin{array}{c}42 \\
(100)\end{array}$ & \multirow{2}{*}{0.245} \\
\hline & No & $\begin{array}{c}5 \\
(10.9)\end{array}$ & $\begin{array}{c}41 \\
(89.1)\end{array}$ & $\begin{array}{c}46 \\
(100)\end{array}$ & \\
\hline \multirow{2}{*}{ HTN } & Yes & $\begin{array}{c}12 \\
(20.7)\end{array}$ & $\begin{array}{c}46 \\
(79.3)\end{array}$ & $\begin{array}{c}58 \\
(100)\end{array}$ & \multirow{2}{*}{0.126} \\
\hline & No & $\begin{array}{c}2 \\
(6.7)\end{array}$ & $\begin{array}{c}28 \\
(93.3)\end{array}$ & $\begin{array}{c}30 \\
(100)\end{array}$ & \\
\hline \multirow{2}{*}{$\begin{array}{c}\text { Duration of } \\
\text { smoking } \\
\text { status }\end{array}$} & $\leq 10$ & $\begin{array}{c}1 \\
(14.3)\end{array}$ & $\begin{array}{c}6 \\
(85.7)\end{array}$ & $\begin{array}{c}7 \\
(100)\end{array}$ & \multirow{2}{*}{1.00} \\
\hline & $>10$ & $\begin{array}{c}10 \\
(18.5) \\
\end{array}$ & $\begin{array}{c}44 \\
(81.5) \\
\end{array}$ & $\begin{array}{c}54 \\
(100) \\
\end{array}$ & \\
\hline \multirow{2}{*}{$\begin{array}{c}\text { Duration of } \\
\text { DM }\end{array}$} & $\leq 5$ & $\begin{array}{c}5 \\
(19.2) \\
\end{array}$ & $\begin{array}{c}21 \\
(80.8) \\
\end{array}$ & $\begin{array}{c}26 \\
(100)\end{array}$ & \multirow{2}{*}{0.711} \\
\hline & $>5$ & $\begin{array}{c}4 \\
(25) \\
\end{array}$ & $\begin{array}{c}12 \\
(75) \\
\end{array}$ & $\begin{array}{c}16 \\
(100)\end{array}$ & \\
\hline \multirow{2}{*}{$\begin{array}{c}\text { Duration of } \\
\text { HTN }\end{array}$} & $\leq 2$ & $\begin{array}{c}3 \\
(25)\end{array}$ & $\begin{array}{c}9 \\
(75)\end{array}$ & $\begin{array}{c}12 \\
(100)\end{array}$ & \multirow{2}{*}{0.702} \\
\hline & $>2$ & $\begin{array}{c}9 \\
(20)\end{array}$ & $\begin{array}{c}36 \\
(80)\end{array}$ & $\begin{array}{c}45 \\
(100)\end{array}$ & \\
\hline \multirow{2}{*}{ ASA Status } & I & $\begin{array}{c}5 \\
(11.9)\end{array}$ & $\begin{array}{c}37 \\
(88.1)\end{array}$ & $\begin{array}{c}42 \\
(100)\end{array}$ & \multirow{2}{*}{0.391} \\
\hline & II & $\begin{array}{c}9 \\
(19.6)\end{array}$ & $\begin{array}{c}37 \\
(80.4)\end{array}$ & $\begin{array}{c}46 \\
(100)\end{array}$ & \\
\hline
\end{tabular}

\section{DISCUSSION}

Recent studies have reported more than 900000 cases occur annually, with one-third of those ultimately having a fatal pulmonary. ${ }^{2,3}$ Patients presenting with DVT in general surgery field report around $40 \%$ cases which develop in absence of prophylaxis \& with a 2-fold increase in incidence if the patient has a coexistent malignant case. ${ }^{4}$ Previous evidence suggested that one third patients having high risk abdominal surgeries received no VTE prophylaxis, While one-half received inadequate preventive measures. ${ }^{5}$ Surgeons have long resisted adoption of aggressive chemoprophylaxis methods because of bleeding concerns. However, more recent data suggest that patients in general surgery developing complications like www.apmcfmu.com 
bleeding, who received prophylaxis occur in $<3 \%$ of cases, and these complications are reduced when lower-dose chemoprophylaxis is used. ${ }^{6}$

While the frequency and severity at VT is well documented in several surgical subspecialties, data regarding DVT development in patients with general surgeries is less compelling. A study in Uganda showed 5\% prevalence of DVT in patients who underwent abdominal surgery. ${ }^{8}$ In another study, Upper extremity DVTsoccurredin40\%; lower extremity DVTs occurred in $45.7 \%$ in patients who underwent surgery. ${ }^{9}$ The frequency of postoperative DVT after high-risk surgery in a local study was found to be $12.82 \% .10$

In this study, female preponderance was found to be higher, i.e. $47(53.40 \%)$. Mean BMI was $25.3 \pm 5.4 \mathrm{Kg} / \mathrm{m}^{2}$. There were 58 (65.9\%) patients with HTN, 34 (38.60\%) smokers and 42 (47.70\%) diabetic patients. DVT frequency was 14 (15.9\%) patients.

Globally DVT is one of the preventable morbidities and mortality affecting $0.1 \%$ patients every year. ${ }^{11,12}$ Both sexes are equally afflicted by a first VTE, men having a higher risk of recurrent thrombosis. ${ }^{13,14}$ DVT is predominantly a disease of the elderly with an incidence that rises markedly with age..$^{12}$

Studies have reported African Americans to be highly affected group due to DVT. Hispanic patients' risk is about half that of Caucasians. Probability of recurrence in Caucasians is lower than that of African-Americans and Hispanics. ${ }^{15-17}$ The highest incidence in childhood is in neonatal period, followed by another peak in adolescence. ${ }^{18}$

The incidence rate is comparatively higher in adolescent females because of pregnancy and oral contraceptives use. ${ }^{19}$ Pregnant women have a much higher risk of VTE than nonpregnant women of similar age and the risk has been shown to be higher after cesarean section than after vaginal delivery. ${ }^{20}$

In a study conducted in an African population, the documented rate was 48 DVT per 100,000 births per year. ${ }^{21}$ The incidence appears to be highest in the postpartum period. The approximate risk for DVT following general surgery procedures is $15 \%$ to $40 \%$. Studies have reported $0.1 \%$ to $2 \%$ risk of those undergoing elective hip replacement and up to $2.5 \%$ to $7.5 \%$ of those undergoing surgery for hip fracture..$^{21,22}$ Though regarded mainly as a surgical complication, most symptomatic VTE events and fatal PE occur in medical patients.

Through a multicenter, prospective, epidemiological study, it was found that incidence is higher in Japan, and almost comparable with that in the Western countries. In this study population, DVT was identified in $41(23.7 \%)$ of 173 patients. This frequency of DVT seemed comparable with that (15-19\%) in Caucasian patients undergoing general or gynecologic surgery. ${ }^{21-22}$ The frequency of symptomatic PTE was $0.6 \%$ $(1 / 173)$, less than that in the Caucasian population $(0.5-1.6 \%)$. One of the two patients complaining of dyspnea was diagnosed as PTE. The incidence of PTE in this study was $0.6 \%$ (1/173). It may be comparable with that $(0.5-1.6 \%)$ in the Caucasian population. ${ }^{21,22}$

Older female patients undergoing longer, intra-pelvic surgery were more likely to be susceptible to VTE. These results are mostly consistent with the general features of VTE reported in Japan and Western countries. ${ }^{4,5}$

Malignancy is generally considered to be a major risk factor for VTE $20-22$ but it was not identified as a significant risk factor in our study. This is probably because of the fact that the number of patients was one-sided toward the malignant population; thereby the statistical significance of malignancy might not be precisely evaluated in this study. Gender predisposition in VTE development is not well investigated in the Japanese surgical population, and still controversial even in the general population..$^{22}$

Frequent occurrence of VTE in surgical populations has been observed in other Asian countries. ${ }^{21}$ One probable elucidation for these findings may be that as in the other Asian countries; Japanese dietary habits and/or lifestyle have become more Westernized over the last several decades. In addition, more extensive surgeries tend to be performed for abdominal malignancy even in aged patients because of advancements in anesthesia, perioperative care, and surgical techniques.

The type of anesthesia is also important in the postoperative development of VTE. Indwelling central venous catheters, a recently recognized major risk factor, been widely applied after the abdominal surgery. Most patients in several studies had malignancy, classified as a major risk factor. Elastic bandages/elastic stockings were shown to be effective in Japanese surgical patients in a prospective study.

However, the mechanical methods of thromboprophylaxis might be generally weak, and there is insufficient evidence for use in the high-risk patients. ${ }^{21-22}$

\section{CONCLUSION}

The frequency of deep venous thrombosis was found in 14 $(15.90 \%)$ patients after abdominal surgery.

\section{LIMITATIONS}

Its results cannot be generalized as sample size of the study is small.

\section{SUGGESTIONS / RECOMMENDATIONS}

More studies are recommended in future research on larger sample size.

\section{CONFLICT OF INTEREST / DISCLOSURE}

There is no conflict of interest involved.

\section{REFERENCES}

1. Guyatt GH, Akl EA, Crowther M, Gutterman DD, Schuünemann HJ. American College of Chest Physicians, Antithrombotic therapy and prevention of thrombosis American college of chest physicians' evidence-based clinical practice guidelines. Chest. 2012;141(2):7-47.

2. Jimenez D, Aujesky D, Moores L, Gomez V, Lobo JL, Uresandi FO, et al. Simplification of the pulmonary embolism serverity index for prognostication in patients with acute symptomatic pulmonary embolism. Arch Intern Med. 2010;170(15):1383-9.

3. Naess IA, Christiansen SC, Romundstad P, Cannegieter SC, Rosendaal FR, Hammerstrøm J. Incidence and mortality of 
venous thrombosis: a population-based study. J Thromb Haemost. 2007;5(4):692-9.

4. Jang MJ, Bang SM, Oh D. Incidence of venous thromboembolism in Korea: from the Health Insurance Review and Assessment Service database. J Thromb Haemost. 2011;9(1):85-91.

5. White $\mathrm{RH}$, Keenan $\mathrm{CR}$. The effects of race/ethnicity and sex on the risk of venous thromboembolism. Curr Opin Pulm Med. 2007;13(5):377-83.

6. JCS Joint Working Group. JCS Guidelines for the diagnosis, treatment and prevention of pulmonary thromboembolism and deep vein thrombosis (JCS 2009). Circ J. 2011;75(5):1258-81.

7. Fujita $Y$, Nakatsuka $H$, Namba $Y$, Mitani $S$, Yoshitake $N$, Sugimoto $E$, et al. The incidence of pulmonary embolism and deep vein thrombosis and their predictive risk factors after lower extremity arthroplasty: a retrospective analysis based on diagnosis using multidetector CT. J Anesth. 2015;29(2):235-41.

8. Parasuraman S, Goldhaber SZ. Venous thromboembolism in children. Circulation. 2006;113(5):12-6.

9. Agterof MJ, Schutgens RE, Snijder RJ, Epping G, Peltenburg HG, Posthuma EF, et al. Out of hospital treatment of acute pulmonary embolism in patients with a low NT-proBNP level. J Thromb Haemost. 2010;8(6):1235-41.

10. Konstantinides SV, Torbicki A, Agnelli G, Danchin N, Fitzmaurice D, Galie N, et al. 2014 ESC guidelines on the diagnosis and management of acute pulmonary embolism. Eur Heart J. 2014;35(43):3033-69.

11. Gader AA, Haggaz A, Adam I. Epidemiology of deep venous thrombosis during pregnancy and puerperium in Sudanese women. Vasc Health Risk Manag. 2009;5(1):85-7.

12. Tsikouras $P$, von Tempelhoff GF, Rath W. Epidemiology, risk factors and risk stratification of venous thromboembolism in pregnancy and the puerperium. Z Geburtshilfe Neonatol. 2017;221(4):161-74.
13. Hirsh J, Guyatt G, Albers GW, Harrington R, Schunemann HJ; The American College of Chest Physicians. Antithrombotic and thrombolytic therapy: American College of Chest Physicians evidence- based clinical practice guidelines, 8th ed. Chest. 2008;133(6):110-12.

14. Righini M, Perrier A, De Moerloose P, Bounameaux H. D-Dimer for venous thromboembolism diagnosis: 20 years later. J Thromb Haemost. 2008;6(7):1059-71.

15. Ghazvinian R, Gottsäter A, Elf JL. Efficacy and safety of outpatienttreatment with direct oral anticoagulation in pulmonaryembolism. J Thromb Thrombolysis. 2018;45(2):319-24.

16. Stone J, Hangge $P$, Albadawi $H$, Wallace A, Shamoun F, Knuttien $M G$, et al. Deep vein thrombosis: pathogenesis, diagnosis, and medical management. Cardiovasc Diagn Ther. 2017;7(3):276-84.

17. Brooks EG, Trotman W, Wadsworth MP, et al. Valves of the deep venous system: an overlooked risk factor. Blood. 2009;114(6):1276-9.

18. Mitchell RN. Hemodynamic disorders, thromboembolic disease and shock. In Kumar V, Abbas AK, Fausto N. Robbins and Cotran Pathologic Basis of Disease. 7th ed. India: Elsevier; 2009:133.

19. Giordano NJ, Jansson PS, Young MN, Hagan KA, Kabrhel C. Epidemiology, pathophysiology, stratification, and natural history of pulmonary embolism. Tech VascInterv Radiol. 2017;20(3):135-40.

20. Bashir R, Zack CJ, Zhao H, et al. Comparative outcomes of catheter-directed thrombolysis plus anticoagulation vs anticoagulation alone to treat lower-extremity proximal deep vein thrombosis. JAMA Intern Med 2014;174(9):1494-501.

21. Behravesh $S$, Hoang $P$, Nanda $A$, et al. Pathogenesis of Thromboembolism and Endovascular Management. Thrombosis 2017;2017:3039713.

22. Streiff MB, Agnelli G, Connors JM, et al. Guidance for the treatment of deep vein thrombosis and pulmonary embolism. J Thromb Thrombolysis. 2016;41(1):32-67.

\section{AUTHORSHIP AND CONTRIBUTION DECLARATION}

\begin{tabular}{|c|c|c|}
\hline AUTHORS & Contribution to The Paper & Signatures \\
\hline $\begin{array}{l}\text { Dr. Tahir Aslam } \\
\text { Consultant Surgeon, Department of Surgery } \\
\text { Bolan Medical Complex Hospital Quetta Pakistan }\end{array}$ & Data Collection \& Manuscript Writing & \\
\hline $\begin{array}{l}\text { Dr. Shahzada Amir } \\
\text { Assistant Professor, Department of Surgery } \\
\text { Bolan Medical Complex Hospital Quetta Pakistan }\end{array}$ & Researcher, Data Collection \& Processing of Data & \\
\hline $\begin{array}{l}\text { Dr. Saira Batool } \\
\text { Consultant Surgeon, Department of Surgery } \\
\text { Bolan Medical Complex Hospital Quetta Pakistan }\end{array}$ & Proof Reading, Authentication of References & \\
\hline $\begin{array}{l}\text { Dr. Nabeela Zia } \\
\text { Senior Registrar, Pediatric Medicine, The Children's } \\
\text { Hospital and Institute of Child Health Lahore Pakistan }\end{array}$ & Data Analysis, Data Collection & \\
\hline $\begin{array}{l}\text { Dr. Muhammad Saleem Iqbal } \\
\text { Assistant Professor of Surgery } \\
\text { Faisalabad Medical University, Faisalabad Pakistan }\end{array}$ & Literature Review & \\
\hline $\begin{array}{l}\text { Dr. Samia Rasool Tabassum } \\
\text { Senior Registrar, Surgery } \\
\text { Abwa Hospital \& Medical College, Faisalabad Pakistan }\end{array}$ & Compiling of Results & \\
\hline $\begin{array}{l}\text { Arslan Ahmed Salam } \\
\text { Research Officer, Pakistan Health Research Council, } \\
\text { (PHRC) Islamabad Pakistan }\end{array}$ & Data Analysis, Approval of Final Draft & \\
\hline
\end{tabular}

